\title{
DEVELOPMENT, PHYSICAL-CHEMICAL CHARACTERIZATION AND IN VITRO ANTIBACTERIAL ACTIVITY EVALUATION OF A FIXED-DOSE COMBINATION ISOHYDRAFURAL-METHYLURACIL HYDROPHILIC OINTMENT
}

\author{
LUCIA MARIA RUS ${ }^{1 \#}$, ELENA DONICI ${ }^{2 \#}$, VLADIMIR VALICA ${ }^{2,3}$, VIOREL PRISACARI $^{4}$, \\ IOAN TOMUȚ $\breve{A}^{5}$, DIANA ȘEPELI ${ }^{6}$, SIMONA CODRUȚA HEGHEȘ ${ }^{1}$, CRISTINA ADELA IUGA ${ }^{1,7 *}$, \\ LIVIA UNCU ${ }^{2,3}$ \\ I "Iuliu Hațieganu” University of Medicine and Pharmacy, Faculty of Pharmacy, Department of Pharmaceutical Analysis, 6 \\ Louis Pasteur, 400349 Cluj-Napoca, Romania \\ 2 "Nicolae Testemițanu” State University of Medicine and Pharmacy, Faculty of Pharmacy, Department of Pharmaceutical \\ and Toxicological Chemistry, Chişinău, Republic of Moldova \\ 3 "Nicolae Testemițanu" State University of Medicine and Pharmacy, Scientific Center of Medicine, Chișinău, Republic of Moldova \\ 4 "Nicolae Testemițanu” State University of Medicine and Pharmacy, Scientific Laboratory "Hospital infections”, Chișinău, \\ Republic of Moldova \\ 5 "Iuliu Hațieganu" University of Medicine and Pharmacy Cluj-Napoca, Faculty of Pharmacy, Department of Pharmaceutical \\ Technology and Biopharmaceutics, 41 Victor Babeș, 400012 Cluj-Napoca, Romania \\ ${ }^{6}$ The Institute of Chemistry of the Academy of Sciences of Moldova, 3 Academiei, Chișinău, Republic of Moldova \\ 7 "Iuliu Hațieganu" University of Medicine and Pharmacy, Department of Proteomics and Metabolomics, MedFuture - Research \\ Centre for Advanced Medicine, 8 Victor Babeș, 400000 Cluj-Napoca, Romania
}

*corresponding author:iugac@umfcluj.ro

${ }^{\#}$ Authors with equal contribution

Manuscript received: April 2019

\begin{abstract}
This research was focused on the pharmaceutical development of a novel, fixed-dose combination isohydrafural-methyluracil ointment on a water soluble base - polyethylene glycol (PEG). Differential scanning calorimetry (DSC) and Fourier transform infra-red spectroscopy (FTIR) were applied in order to determine the compatibility between active pharmaceutical ingredients (APIs) and between APIs - excipients. Nine formulations (F1 - F9) were tested for: physical appearance and homogeneity, $\mathrm{pH}$, viscosity and osmotic activity. The optimal formulation presented the concentrations of PEG 400 $76.72 \%$, PEG $1500-19.18 \%$ and a fixed-dose combination of $0.1 \%$ isohydrafural and $4 \%$ methyluracil. It showed higher antibacterial properties both to Gram-positive and Gram-negative bacteria than nitrofural $2 \%$ ointment (Furacilin ${ }^{\circledR}$, Belarus). The long-term stability testing of the optimized formulation of isohydrafural and methyluracil revealed the shelf-life of two years.
\end{abstract}

\section{Rezumat}

Această cercetare s-a axat pe dezvoltarea farmaceutică a unui unguent nou, cu combinații fixe de izohidrafural-metiluracil într-o bază hidrosolubilă - de polietilenglicol. Analiza calorimetrică diferențială (DSC) și spectroscopia în infraroșu cu transformantă Fourier (FTIR) au fost aplicate pentru a determina compatibilitatea dintre substanţele active precum şi dintre substanțe active și excipienți. Au fost testate nouă formulări privind: aspectul fizic și omogenitatea, pH-ul, vâscozitatea şi activitatea osmotică. Formularea optimă a prezentat concentrațiile de PEG 400 - 76,72\%, PEG 1500 - 19,18\% și o combinație de doze fixe de $0,1 \%$ izohidrafural și $4 \%$ metiluracil. Aceasta a prezentat proprietăți antibacteriene superioare atât pentru bacteriile Gram-pozitive cât și pentru cele Gram-negative, față de unguentul de nitrofural $2 \%$ (Furacilin ${ }^{\circledR}$, Belarus). În urma studiilor de stabilitate în timp real efectuate asupra formulării optimizate a unguentului cu izohidrafural şi metiluracil s-a stabilit termenul de valabilitate de doi ani.

Keywords: pharmaceutical preformulation, stability evaluation, in vitro antibacterial activity

\section{Introduction}

Skin and soft tissue infections are considered to be one of the most prevalent disorders [16]. Worldwide it is estimated that $7 \%$ to $10 \%$ of hospitalized patients are affected by skin and soft tissue infections [6] and are the third most common diagnosis in the emergency care setting. Although, their incidence and prevalence are highly variable, because patients can resort to self-medication and not to call medical examination or hospitalization [16].

Bacterial skin and soft tissue infections usually require topical antibiotics for first-line therapy [16]. 
FARMACIA, 2019, Vol. 67, 5

In a period in which more and more bacteria develop resistance to antibiotics, the use of antimicrobial drugs may be very helpful $[5,12,14,30]$. Isohydrafural (isonicotinoyl hydrazone of 5-nitro-2furan aldehyde) is a derivative of 5-nitrofuran, which was synthesized by a group of researchers from the Republic of Moldova [24]. Isohydrafural has significant antibacterial properties against both aerobic and anaerobic bacteria, from 2 to 7 times higher than nitrofural $[11,23]$. It has bactericidal activity in concentrations between $1.25-5.0 \mu \mathrm{g} / \mathrm{mL}$, of all investigated strains of Staphylococcus genus $[11,21]$. Also, isohydrafural is less toxic $\left(\mathrm{LD}_{50}=\right.$ $990 \mathrm{mg} / \mathrm{kg}$ ) than nitrofural $\left(\mathrm{LD}_{50}=166.7 \mathrm{mg} / \mathrm{kg}\right)$. A major advantage of this API is that it is an antimicrobial compound effective for topical application [22].

Usually the treatment of skin and soft tissue infections is a long term one, which requires also the use of drugs with regenerative action. Methyluracil is a pyrimidine derivative (2,4-dihydroxy-6-methylpyrimidine) with antiinflammatory, immune stimulating and photo-protective action on the skin [25].

The hydrophilic ointment base has an important role in formulation of ointments. PEG is a water soluble base and is preferred by patients, because of its easy removal by washing. Also, PEG is considered to be the most suitable base for semi-solid dosage forms for the treatment of skin and soft tissue infections, because it can absorb the exudate maintaining moisture balance in an infected wound [13].

This research comes with original contributions on development of a fixed-dose combination hydrophilic ointment for the treatment of skin and soft tissue infections. It was used a new antimicrobial substance, effective for topical application - isohydrafural. Also, there are no other published studies on combination of isohydrafural-methyluracil together in a single topical dosage form.

The goal of the study was to develop a fixed-dose combination of $0.1 \%$ isohydrafural - $4 \%$ methyluracil ointment on a water soluble base of PEG, to evaluate its in vitro antibacterial activity and also to determine its stability and shelf-life during long-term storage.

\section{Materials and Methods}

\section{Materials}

Isohydrafural was synthesized at the Organic Chemistry Department, State University of Moldova from Chișinău, Republic of Moldova ( $99.9 \%$ concentration). The internal standard of isohydrafural was purified by crystallization and drying (99.9\% concentration). Methyluracil (6-methyluracil) was purchased from Sigma Aldrich, Saint Quentin Fallavier, France (99.9\% concentration). PEG 400 and PEG 1500 were purchased from Sigma Aldrich, Saint Quentin Fallavier, France. Different formulations containing a fixed-dose combination of $0.1 \%$ isohydrafural and $4 \%$ methyluracil and prepared by varying PEG 400 and PEG 1500 in different ratios and isohydrafural $0.05 \%$ and $0.1 \%$ ointments, which contains: isohydrafural, PEG 400 and PEG 1500 and commercial Furacilin $^{\circledR} 2 \%$ ointment, Belarus, which contains: nitrofural and vaseline. Deionized water, methanol (HPLC grade).

Preformulation compatibility studies

Differential Scanning Calorimetry (DSC)

DSC was performed using Mettler Toledo DSC 822 cell, aluminium crucibles $40 \mu \mathrm{L}$ with about $2 \mathrm{mg}$ of samples, under dynamic $\mathrm{N}_{2}$ atmosphere (flow rate: $50 \mathrm{~mL} / \mathrm{min}$ ) and at a heating rate of $10^{\circ} \mathrm{C} / \mathrm{min}$ in the temperature range from 25 to $400^{\circ} \mathrm{C}$. A $40 \mu \mathrm{L}$ aluminium crucible closed with a perforated cap was used as a reference. Calibration of the apparatus was done using an indium standard in an aluminium $40 \mu \mathrm{L}$ crucible.

The APIs isohydrafural and methyluracil, the individual excipients PEG 400 and PEG 1500 as well as the physical, binary mixtures of isohydrafural/methyluracil, isohydrafural/PEG 400, isohydrafural/PEG 1500, methyluracil/PEG 400 and methyluracil/PEG 1500 in the ratio of $1: 1(\mathrm{w} / \mathrm{w})$ were tested. DSC thermograms were stored and processed using STAR SW 12.10 software. The data obtained from the analysis of samples of APIs and individual excipients were compared with those obtained from the analysis of binary $1: 1(\mathrm{w} / \mathrm{w})$ mixtures in order to identify possible interactions.

FTIR spectroscopy (FTIR)

FTIR spectroscopy was performed using Perkin Elmer Spectrum 100 FTIR Spectrometer with Attenuated Total Reflection (ATR) Accessory. The scanning range was between $4000 \mathrm{~cm}^{-1}$ and $400 \mathrm{~cm}^{-1}$. The APIs, the individual excipients PEG 400 and PEG 1500 as well as the physical, binary mixtures of isohydrafural/methyluracil, isohydrafural/PEG 400, isohydrafural/PEG 1500, methyluracil/PEG 400 and methyluracil/PEG 1500 in the ratio of $1: 1(\mathrm{w} / \mathrm{w})$ were tested.

The FTIR spectra obtained from the analysis of samples of pure substances were compared with those obtained from the analysis of mixtures in order to identify the possible interactions.

\section{Ointment formulation and evaluation}

Preparation of formulations. Nine formulations were prepared by varying PEG 400 and PEG 1500 in different ratios (Table I). The technology of preparation of nine formulations: accurately weighed mass of $0.1 \mathrm{~g}$ of isohydrafural and $4.0 \mathrm{~g}$ of methyluracil were dissolved in $3.0 \mathrm{~g}$ of PEG 400. Then the remaining amount of PEG 400 was mixed with PEG 1500 at $55-60^{\circ} \mathrm{C}$ for 20 minutes. The obtained liquid of active substances was added to the hydrophilic base of PEG's mixture under stirring. The ointments were allowed to cool down at room temperature. 


\begin{tabular}{cccccccccc}
\hline \multirow{2}{*}{ Components } & \multicolumn{10}{c}{ Composition of the formulations (g) } \\
& F1 & F2 & F3 & F4 & F5 & F6 & F7 & F8 & F9 \\
\hline Isohydrafural & 0.1 & 0.1 & 0.1 & 0.1 & 0.1 & 0.1 & 0.1 & 0.1 & 0.1 \\
Methyluracil & 4.0 & 4.0 & 4.0 & 4.0 & 4.0 & 4.0 & 4.0 & 4.0 & 4.0 \\
PEG 400 & 19.18 & 63.93 & 67.69 & 76.72 & 70.66 & 82.20 & 57.54 & 83.91 & 61.03 \\
PEG 1500 & 76.72 & 31.97 & 28.21 & 19.18 & 25.24 & 13.70 & 38.36 & 11.99 & 34.87 \\
Total & $\mathbf{1 0 0 . 0}$ & $\mathbf{1 0 0 . 0}$ & $\mathbf{1 0 0 . 0}$ & $\mathbf{1 0 0 . 0}$ & $\mathbf{1 0 0 . 0}$ & $\mathbf{1 0 0 . 0}$ & $\mathbf{1 0 0 . 0}$ & $\mathbf{1 0 0 . 0}$ & $\mathbf{1 0 0 . 0}$ \\
\hline
\end{tabular}

Physical appearance and homogeneity were tested by visual observation.

pH measurement was determined by using the $\mathrm{pH}$ meter Consort C861. $1.0 \mathrm{~g}$ of ointment was dissolved in $25 \mathrm{~mL}$ of deionized water by heating at $37^{\circ} \mathrm{C}$. The obtained solution was cooled at room temperature and then filtered. The measurements were carried out in triplicate.

Viscosity

Viscosity was determined by using Rotational Viscometer Multi Visc Rheometer, Fungilab (Spain) with R7 spindle at $3 \mathrm{rpm}$ speed, at $22 \pm 0.1^{\circ} \mathrm{C}$ and $37 \pm 0.1^{\circ} \mathrm{C}$. The values were read in centipoises $[18,20]$.

Osmotic activity

The osmotic activity was determined by in vitro dialysis method. A dialysis device, consisted of a $30 \mathrm{~mm}$ diameter glass tube with a cellophane membrane attached at one end, was used. On the inner side, about $0.1 \mathrm{~g}$ ointment was placed on cellophane. The dialysis device with ointment was weighed with an accuracy of $0.00001 \mathrm{~g}$ and was placed in a vessel with purified water, at $35 \pm 1.0^{\circ} \mathrm{C}$. After each hour, the dialysis tube containing the ointment sample was removed and weighed on an analytical balance. The experiment finished after 6 hours. The value of osmotic activity was evaluated gravimetrically and expressed as a percentage of the initial mass of the ointment [32].

In vitro antibacterial activity was studied for the optimized formulation. The method of diffusion into agar was applied [26]. The cell cultures were grown on a liquid nutrient medium of $2 \%$ meat peptone broth with $\mathrm{pH}$ 7. The following reference strains were used: Staphylococcus aureus (209), Enterococcus faecalis (ATCC 25922), Escherichia coli (ATCC 25922), Pseudomonas aeruginosa (ATCC 27853), Proteus vulgaris (HX 19222), Klebsiella pneumoniae (ATCC 13883).

The investigated strains, grown for 18 hours on the inclined peptonate agar, were washed with $0.9 \%$ isotonic sodium chloride solution and diluted to the optical turbidity standard to obtain the inoculums containing 1 million cells per $\mathrm{mL}$. Then the inoculums were diluted with ointment suspensions in dimethylformamide and meat peptone broth in a ratio of $1: 1$. The tubes were incubated at $37^{\circ} \mathrm{C}$ for 24 and 48 hours. The control samples were the nutrient media with the same strains without the investigated ointment.
The evaluation of the results was made visually. The Minimum inhibitory concentration (MIC) was established by the absence of growth of microorganisms in the liquid nutrient medium. The Minimum bactericidal concentration (MBC) was determined by the absence of microorganisms growth, after repeated incubated on peptone gelatine incubated for 24 and 48 hours. Stability studies

The stability study was done by real-time method according to ICH guidelines $[1,3,31]$ for the optimized formulation (F4). The storage conditions were: $25 \pm$ $2{ }^{\circ} \mathrm{C}$ and $60 \pm 5 \% \mathrm{RH}$ for a period of 24 months. F4 was packed in dark glass container. The stability samples were analysed for physical appearance and homogeneity, $\mathrm{pH}$, viscosity, drug content and in vitro antibacterial activity at $0,3,6,9,12,18,24$ and 30 months.

The quantitative determination of isohydrafural and methyluracil from the optimized formulation was performed by HPLC. The method has been previously developed and validated based on International Conference of Harmonization (ICH) guideline Q2 (R1) [2]. The apparatus consisted of an Agilent Technologies 1220 Infinity LC with a variable wavelength detector. The separation was performed using a chromatographic Core-shell silica column C18 with dimensions $5.0 \times 30.0 \mathrm{~mm}$ and particle size $2.6 \mu \mathrm{m}$ (Phenomenex, Kinetex). The mobile phase consisted of methanol and deionized water in the ratio of 25:75. The flow rate was $0.4 \mathrm{~mL} / \mathrm{min}$ and the volume of injection was $20 \mu \mathrm{L}$. The column temperature was set at $30^{\circ} \mathrm{C}$. The analytes were detected at $260 \mathrm{~nm}$ wavelength. In those chromatographic conditions the retention time was $17.02 \mathrm{~min}$ for isohydrafural and $1.54 \mathrm{~min}$ for methyluracil respectively.

Preparation of standard solution of isohydrafural: $10 \mathrm{mg}$ of isohydrafural working standard was accurately weighed and transferred into a $100 \mathrm{~mL}$ volumetric flask. About $30 \mathrm{~mL}$ of mobile phase was added and mixed until isohydrafural was dissolved. The sample was made up to the mark with mobile phase. $1 \mathrm{~mL}$ of obtained solution was transferred into a $10 \mathrm{~mL}$ volumetric flask and was made up to the mark with mobile phase.

Preparation of standard solution of methyluracil: $40 \mathrm{mg}$ of methyluracil working standard was accurately weighed and transferred into a $100 \mathrm{~mL}$ volumetric flask. About $30 \mathrm{~mL}$ of mobile phase was added and 
mixed until methyluracil was dissolved. The sample was made up to the mark with mobile phase. $1 \mathrm{~mL}$ of obtained solution was transferred into a $10 \mathrm{~mL}$ volumetric flask and was made up to the mark with mobile phase.

Preparation of the ointment sample: about $1.0 \mathrm{~g}$ of ointment was accurately weighed and transferred into a porcelain cup. About $10 \mathrm{~mL}$ of mobile phase was added and was heated in a water bath at $60^{\circ} \mathrm{C}$ until the ointment was melted. The sample was allowed to cool at room temperature and was filtered and collected into a $50 \mathrm{~mL}$ volumetric flask. The extraction was repeated twice with each $20 \mathrm{~mL}$ mobile phase. The obtained samples were added to the first extraction solution and were made up to the mark with mobile phase. Further $5 \mathrm{~mL}$ were transferred into a $10 \mathrm{~mL}$ volumetric flask and was made up to the mark with mobile phase.

Statistical Analysis

The results of experiments, which were performed in triplicate, were reported as mean \pm standard deviation (SD). Statistical measurements were carried out by using the Statistical Package for the Social Sciences (IBM SPSS Statistics) 10.5 software.

\section{Results and Discussion}

Preformulation compatibility studies

Differential Scanning Calorimetry (DSC)

DSC method is frequently used as a rapid tool to determine the potential physical and chemical interactions between drug-drug and drug-excipient in the preformulation stage $[4,7,8,10,15,27-29]$. The thermograms of the two API's, the excipients as well as their 1:1 (w/w) physical mixtures were recorded. The apparition of a potential incompatibility was considered when a shift in the melting point, changes in the peak shape or area, the development of a new transition comparing to those observed in the initial thermograms, the increase or decrease in the number of peaks due to the mixture of components were recorded [9].

The thermograms of isohydrafural, methyluracil and their $1: 1(\mathrm{w} / \mathrm{w})$ physical mixture are presented in Figure 1A. Figure 1B contains the thermograms of isohydrafural, PEG 400, PEG 1500 and 1:1 (w/w) physical mixtures isohydrafural: PEG 400 and isohydrafural: PEG 1500. In Figure 1C are presented the thermograms of methyluracil, PEG 400, PEG 1500 and 1:1 (w/w) physical mixtures methyluracil: PEG 400 and methyluracil: PEG 1500.

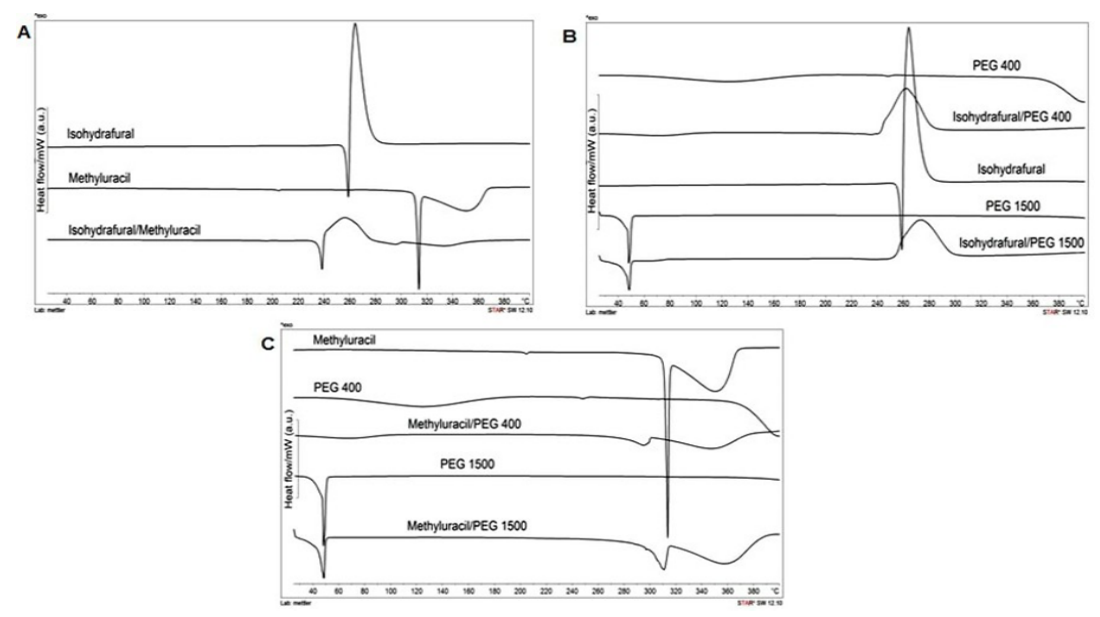

Figure 1.

DSC thermograms of: (A) isohydrafural, methyluracil and isohydrafural:methyluracil 1:1 (w/w) physical mixture; (B) isohydrafural, PEG 400, PEG 1500, isohydrafural/ PEG 400 1:1(w/w) and isohydrafural/ PEG 1500 1:1(w/w); (C) methyluracil, PEG 400, PEG 1500, methyluracil/ PEG 400 1:1(w/w) and methyluracil/ PEG 1500 $1: 1(\mathrm{w} / \mathrm{w})$

The DSC thermogram of isohydrafural (Figures 1A and 1B) presents an endothermic peak between $256.10^{\circ} \mathrm{C}$ and $259.76^{\circ} \mathrm{C}$, with Tpeak $=257.28^{\circ} \mathrm{C}$, corresponding to the melting of isohydrafural. The decomposition of the substance starts concurrently with its melting [9]. The DSC curve of methyluracil (Figures 1A, 1C) presented an endothermic peak between $311.33^{\circ} \mathrm{C}$ $315.08^{\circ} \mathrm{C}$ with $\mathrm{Tpeak}=313.67^{\circ} \mathrm{C}$ corresponding to its melting, followed by decomposition.
In the DSC thermogram of binary mixture of the two APIs (Figure 1A) the melting endotherm of isohydrafural appears between $235.81^{\circ} \mathrm{C}$ and $239.57^{\circ} \mathrm{C}$ (Tpeak $=237.51^{\circ} \mathrm{C}$ ) and is followed by decomposition. In the DSC thermogram of PEG 400 (Figures 1B and $1 \mathrm{C}$ ), the large endothermic event between $60.36^{\circ} \mathrm{C}$ and $180.13^{\circ} \mathrm{C}\left(\mathrm{Tpeak}=124.69^{\circ} \mathrm{C}\right)$ corresponds to dehydration. A second small endothermic event could be seen between $243.32^{\circ} \mathrm{C}$ and $251.81^{\circ} \mathrm{C}$ (Tpeak $=$ $247.63^{\circ} \mathrm{C}$ ) and corresponds to its flashpoint $[19,26]$. 
FARMACIA, 2019, Vol. 67, 5

PEG 1500 presents in its thermogram (Figures 1B and $1 \mathrm{C}$ ) the melting endotherm between $46.71^{\circ} \mathrm{C}$ and $50.36^{\circ} \mathrm{C}\left(\right.$ Tpeak $\left.=47.50^{\circ} \mathrm{C}\right)[26]$.

In the DSC thermogram of binary mixture $1: 1(\mathrm{w} / \mathrm{w})$ isohydrafural: PEG 400 (Figure 1B) the endothermic event that appears between $35.02^{\circ} \mathrm{C}$ and $102.43^{\circ} \mathrm{C}$, corresponds to dehydration of PEG 400, while the second peak, exothermic, corresponds to the decomposition of isohydrafural. The DSC thermogram of binary mixture 1:1 (w/w) isohydrafural: PEG 1500 (Figure 1B) presents the peak corresponding to the melting of the excipient between $45.14^{\circ} \mathrm{C}$ and $49.82^{\circ} \mathrm{C}$ (Tpeak $=48.01^{\circ} \mathrm{C}$ ) and also the decomposition exotherm of isohydrafural.

The DSC thermogram of the binary mixture 1:1 (w/w) of methyluracil and PEG 400 (Figure 1C), presents a first endothermic peak corresponding to dehydration of PEG 400 , between $29.78^{\circ} \mathrm{C}$ and $97.50^{\circ} \mathrm{C}$. The second peak that appears, between $281.51^{\circ} \mathrm{C}$ and $300.08^{\circ} \mathrm{C}$, corresponds to the melting of methyluracil. In case of mixture with PEG 1500 in the DSC thermograms it can be noticed the presence of the excipient melting peak (Tpeak $\left.=48.01{ }^{\circ} \mathrm{C}\right)$ and also the endotherm corresponding to the melting of methyluracil followed immediately by decomposition.

The thermoanalytical data of isohydrafural and methyluracil and their physical mixtures 1:1 (w/w) with excipients are presented in Table II.

Following the DSC compatibility studies using binary mixtures between isohydrafural, methyluracil and the excipients PEG 400 and PEG 1500 we could conclude that possible interactions appear between the components of the binary mixtures because of the disappearance or the shifting of the drugs melting events. Equally we could say that this could be due to the solubilisation/mixing and may not necessarily indicate potential incompatibility. drug/excipient 1:1(w/w) physical mixtures

\begin{tabular}{lccc}
\multicolumn{1}{c}{ Sample } & Tonset $(\mathbf{m e l t i n g})\left({ }^{\circ} \mathbf{C}\right)$ & Tpeak (melting) $\left({ }^{\circ} \mathbf{C}\right)$ & $\Delta$ Hmelting $(\mathbf{J} / \mathbf{g})$ \\
\hline Isohydrafural & 256.10 & 257.28 & 141.85 \\
Isohydrafural +PEG 400 & - & - & - \\
Isohydrafural +PEG 1500 & - & - & - \\
Isohydrafural +Methyluracil & 235.81 & 237.51 & 86.64 \\
Methyluracil & 311.33 & 313.67 & 229.52 \\
Methyluracil +PEG 400 & 281.31 & 294.62 & 60.17 \\
Methyluracil +PEG 1500 & 299.96 & 310.09 & 73.53 \\
Methyluracil+Isohydrafural & - & - & - \\
\hline
\end{tabular}

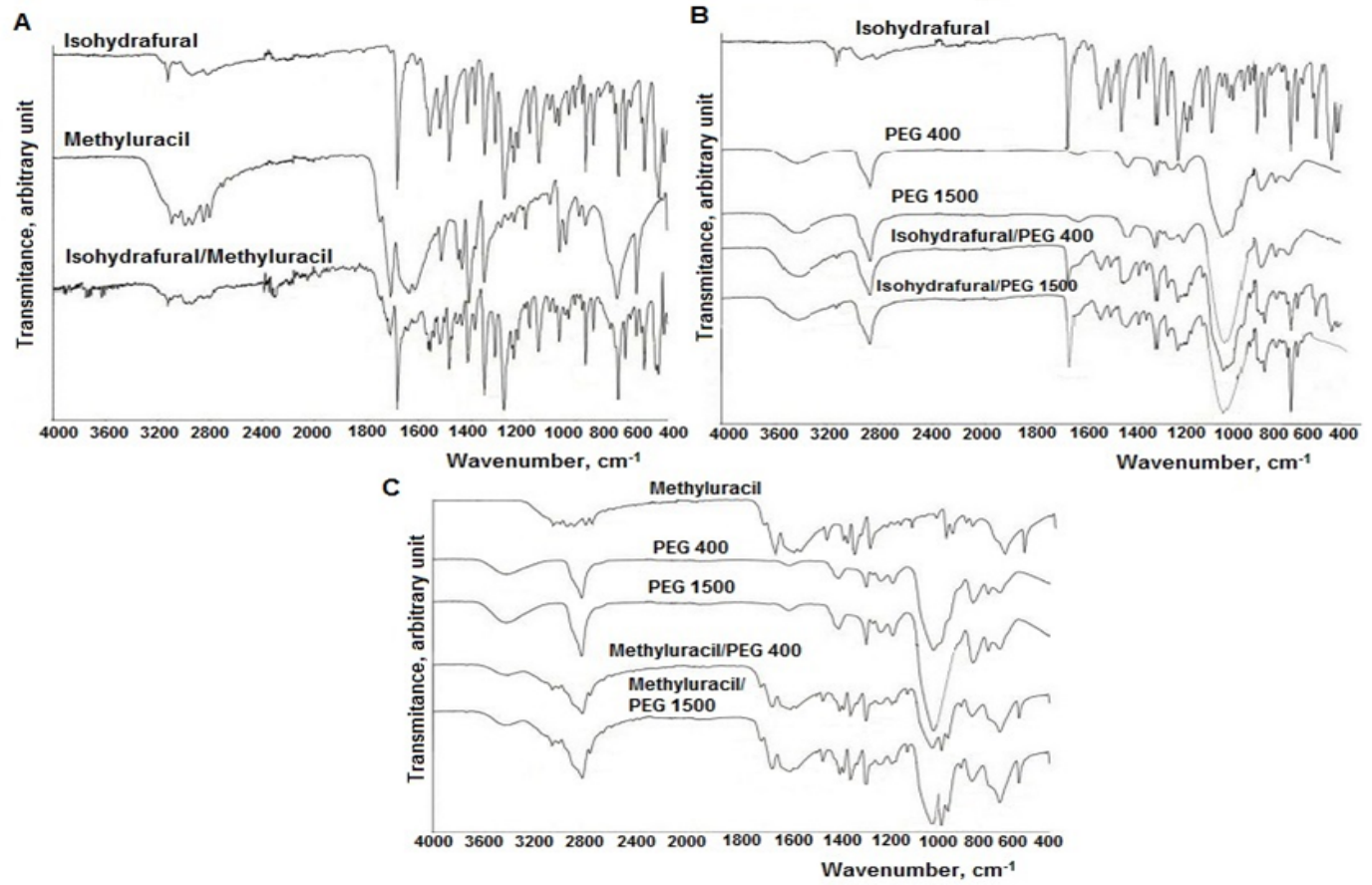

Figure 2.

FTIR spectra of: isohydrafural, methyluracil and isohydrafural/ methyluracil 1: $1(\mathrm{w} / \mathrm{w})$ physical mixture (A); isohydrafural, PEG 400, PEG 1500, isohydrafural/ PEG 400 1:1(w/w) and isohydrafural/ PEG 1500 1:1(w/w) (B); methyluracil, PEG 400, PEG 1500, methyluracil/ PEG 400 1:1(w/w) and methyluracil/ PEG 1500 1:1(w/w) (C) 
FARMACIA, 2019, Vol. 67, 5

FTIR spectroscopy (FTIR)

To confirm and complete the DSC results, the compatibility studies were further conducted using FTIR-spectroscopic method.

The FTIR spectra were interpreted in order to assess the physical and chemical compatibility between the drug substances and between the drug substances and excipients [10, 15, 29].

On FTIR spectrum of standard sample of isohydrafural are presented the vibrations of the furan cycle of at $1681.9 \mathrm{~cm}^{-1}, 932.3 \mathrm{~cm}^{-1}$ and $961.9 \mathrm{~cm}^{-1}$, the peak due to N-O vibrations of nitro group at $1275.2 \mathrm{~cm}^{-1}$, the deformation vibrations of the amide group $\mathrm{NH}-$ $\mathrm{C}=\mathrm{O}$ at $3121.8 \mathrm{~cm}^{-1}$ and the vibrations of $-\mathrm{C}-\mathrm{N}-\mathrm{O}$ at $836.4 \mathrm{~cm}^{-1}$ (Figure 2A). On FTIR spectrum of standard sample of methyluracil are observed the band due to $\mathrm{N}-\mathrm{H}$ vibrations at $1414.5 \mathrm{~cm}^{-1}$, the peak that certified the carbonyl group $\mathrm{C}=\mathrm{O}$ at $1709.7 \mathrm{~cm}^{-1}$ and the band due to an absorption of the methyl group $-\mathrm{CH}_{3}$ at $1349.7 \mathrm{~cm}^{-1}$ (Figure 2A). In the FTIR spectra of pure PEG 400 and PEG 1500, the bands at $3439.8 \mathrm{~cm}^{-1}$ and at $3400 \mathrm{~cm}^{-1}$ respectively occur due to the $\mathrm{O}-\mathrm{H}$ stretching vibrations. The bands at $2867.9 \mathrm{~cm}^{-1}$ and $2870 \mathrm{~cm}^{-1}$ correspond to $\mathrm{C}-\mathrm{H}$ stretching vibrations, while the peaks at $1094.8 \mathrm{~cm}^{-1}$ and $1092.2 \mathrm{~cm}^{-1}$ correspond to $\mathrm{C}-\mathrm{O}-\mathrm{C}$ stretching vibrations (Figures $2 \mathrm{~B}$ and 2C). Similar bands can be seen on FTIR spectra of binary mixtures (Figures 2A, 2B and 2C). The FTIR spectra of 1:1 (w:w) binary mixtures of the two APIs and APIs with PEG 400 and PEG 1500 contain the most characteristic absorption bands of each pure substance, which confirms the physical and chemical compatibility of the active substances and the ointment base.

\section{Ointment formulation and evaluation}

The dose of isohydrafural was determined by assessing the in vitro antibacterial activity of two single ointments of $0.1 \%$ and $0.05 \%$ of isohydrafural, which were prepared on a vehicle of PEG 400 and PEG 1500 in a ratio of $4: 1$ and in comparison with placebo (Table IV). The in vitro antibacterial activity of the $0.1 \%$ isohydrafural ointment against Staphylococcus aureus 209-P, Enterococcus faecalis and Escherichia coli is more potent than that of $0.5 \mathrm{mg} / \mathrm{g}$ isohydrafural ointment. As $1 \mathrm{mg} / \mathrm{g}$ isohydrafural ointment presented higher antibacterial results against the majority examined strains, it was selected the dose of $1 \mathrm{mg} / \mathrm{g}$ of isohydrafural. Also, it was taken into account that the $\mathrm{LD}_{50}$ of isohydrafural is $990 \mathrm{mg} / \mathrm{kg} \mathrm{bw}$.

The use of a hydrophilic vehicle has contributed to reduce the dose of methyluracil to $4 \%$ in comparison to $10 \%$ methyluracil ointment on lipophilic, lanolinevaseline base [33, 34].

Physical appearance and homogeneity

All nine formulations were found to be homogenous, yellowish, without odour preparations.

pH measurement

Also, the $\mathrm{pH}$ values of all nine formulations were found to be within the range of skin $\mathrm{pH}: 5.5$ to 7.0.

Viscosity and Osmotic activity

The formulation with the most optimal viscosity at $22^{\circ} \mathrm{C}$ could be easily removed from the container, while the most optimal viscosity at $37^{\circ} \mathrm{C}$ will allow an easier application on the wounds [35-40].

An optimal osmosis, which should be within the limits $250-300 \%$, will eliminate the exudate and also, will not affect the epithelisation phases [13]. It was found that the viscosity and osmotic activity increased with the increase of concentration of PEG 1500 at both temperatures. The optimal formulation was F4 with the concentrations of $76.72 \%$ of PEG 400 and $19.18 \%$ of PEG 1500 , as it has optimal values of viscosity at both $22^{\circ} \mathrm{C}$ and $37^{\circ} \mathrm{C}$ at the lowest shear rate and it is capable of a high osmotic activity in comparison with the rest of the formulations (Table III) [13, 35-40].

Table III

The results of viscosity at the lowest shear rate and osmotic activity of the formulations

\begin{tabular}{ccccccccccc}
\hline \multirow{2}{*}{ Results } & \multicolumn{6}{c}{ Formulation } \\
\cline { 2 - 8 } & & F1 & F2 & F3 & F4 & F5 & F6 & F7 & F8 & F9 \\
\hline The viscosity at the lowest & $\mathbf{2 2}^{\circ} \mathbf{C}$ & 139.34 & 198.79 & 193.67 & 176.51 & 188.31 & 165.44 & 232.54 & 158.33 & 211.34 \\
shear rate, cP*10 & $\mathbf{3 7}^{\circ} \mathbf{C}$ & 81.96 & 113.56 & 101.93 & 101.41 & 108.81 & 93.47 & 135.22 & 87.96 & 122.16 \\
Osmotic activity, \% & & 202.18 & 348.12 & 301.07 & 301.10 & 303.44 & 202.03 & 361.33 & 201.11 & 358.02 \\
\hline
\end{tabular}

In vitro antibacterial activity

The optimal formulation of the fixed-dose combination $0.1 \%$ isohydrafural $-4.0 \%$ methyluracil ointment was tested to determine the antibacterial activity compared to $0.05 \%$ and $0.1 \%$ izohydrafural ointments and also compared to placebo and the commercial Furacilin ${ }^{\circledR} 2 \%$ ointment, Belarus (Table IV).

The fixed-dose combination $0.1 \%$ isohydrafural $4.0 \%$ methyluracil ointment presented significant antibacterial properties both to Gram-positive and
Gram-negative bacteria, which are due to isohydrafural and, to a lesser extent, to PEGs (Table IV). The hydrophilic fixed-dose ointment had the highest antibacterial activity on the Staphylococcus aureus 209-P, which can cause life-threatening infections in humans, especially in the nosocomial environment [17]. The in vitro antibacterial activity of the fixeddose combination ointment is more potent than that of nitrofural ointment. 
Table IV

In vitro antibacterial activity of the fixed-dose combination $0.1 \%$ isohydrafural $-4.0 \%$ methyluracil ointment in comparison with $0.05 \%$ and $0.1 \%$ izohydrafural ointments, placebo and the commercial Furacilin ${ }^{B} 2 \%$ ointment,

Belarus

\begin{tabular}{|c|c|c|c|c|c|}
\hline \multirow[b]{2}{*}{ Strains } & \multicolumn{5}{|c|}{ MIC/MBC $(\mu \mathrm{g} / \mathrm{mL})$} \\
\hline & $\begin{array}{c}0.1 \% \text { isohydrafural - } \\
4.0 \% \text { methyluracil } \\
\text { ointment }\end{array}$ & $\begin{array}{c}0.05 \% \\
\text { isohydrafural } \\
\text { ointment }\end{array}$ & $\begin{array}{c}0.1 \% \\
\text { isohydrafural } \\
\text { ointment }\end{array}$ & $\begin{array}{c}\text { PEG } 400 \text { and } \\
\text { PEG } 1500 \\
\text { ointment } \\
\text { (placebo) }\end{array}$ & $\begin{array}{c}\text { Furacilin }{ }^{\circledR} 2 \% \\
\text { ointment, } \\
\text { Belarus }\end{array}$ \\
\hline $\begin{array}{l}\text { Staphylococcus } \\
\text { aureus 209-P }\end{array}$ & $0.97 / 0.97$ & $3.9 / 3.9$ & $0.97 / 0.97$ & $25.0 / 25.0$ & $18.7 / 37.5$ \\
\hline $\begin{array}{c}\text { Enterococcus } \\
\text { faecalis }\end{array}$ & $7.8 / 62.5$ & $15.6 / 250$ & $7.8 / 62.5$ & $75.0 / 75.0$ & $37.5 / 75$ \\
\hline Escherichia coli & $3.9 / 3.9$ & $31.25 / 62.5$ & $3.9 / 3.9$ & $50.0 / 50.0$ & $18.7 / 37.5$ \\
\hline $\begin{array}{l}\text { Klebsiella } \\
\text { pneumonia }\end{array}$ & $31.25 / 62.5$ & $31.25 / 62.5$ & $31.25 / 62.5$ & $>300 />300$ & $>300 />300$ \\
\hline $\begin{array}{c}\text { Pseudomonas } \\
\text { aeruginosa }\end{array}$ & $31.25 / 31.25$ & $31.25 / 31.25$ & $31.25 / 31.25$ & $100 / 100$ & $>300 />300$ \\
\hline Proteus vulgaris & $7.8 / 7.8$ & $7.8 / 15.6$ & $7.8 / 7.8$ & $>300 />300$ & $150 / 300$ \\
\hline
\end{tabular}

Table V

Stability results of the fixed-dose combination $0.1 \%$ isohydrafural $-4.0 \%$ methyluracil ointment

\begin{tabular}{|c|c|c|c|c|c|c|c|c|}
\hline \multirow{2}{*}{ Parameters } & \multicolumn{8}{|c|}{ Months } \\
\hline & $\mathbf{0}$ & 3 & 6 & 9 & 12 & 18 & 24 & 30 \\
\hline Appearance & $\begin{array}{l}\text { Y, no } \\
\text { odour }\end{array}$ & $\begin{array}{l}\text { Y, no } \\
\text { odour }\end{array}$ & $\begin{array}{l}\text { Y, no } \\
\text { odour }\end{array}$ & $\begin{array}{l}\text { Y, no } \\
\text { odour }\end{array}$ & $\begin{array}{l}\text { Y, no } \\
\text { odour }\end{array}$ & $\begin{array}{l}\text { Y, no } \\
\text { odour }\end{array}$ & $\begin{array}{l}\text { Y, no } \\
\text { odour }\end{array}$ & $\begin{array}{l}\text { orange, } \\
\text { no odour }\end{array}$ \\
\hline Homogeneity & $\mathrm{H}$ & $\mathrm{H}$ & $\mathrm{H}$ & $\mathrm{H}$ & $\mathrm{H}$ & $\mathrm{H}$ & $\mathrm{H}$ & $\mathrm{H}$ \\
\hline $\mathrm{pH}($ mean $\pm \mathrm{SD}, \mathrm{n}=3)$ & $\begin{array}{c}5.66 \pm \\
0.01\end{array}$ & $\begin{array}{c}5.65 \pm \\
0.01\end{array}$ & $\begin{array}{c}5.64 \pm \\
0.02\end{array}$ & $\begin{array}{c}5.67 \pm \\
0.01\end{array}$ & $\begin{array}{c}5.68 \pm \\
0.02\end{array}$ & $\begin{array}{l}5.62 \pm \\
0.02\end{array}$ & $\begin{array}{c}5.63 \pm \\
0.02\end{array}$ & $\begin{array}{c}4.78 \pm \\
0.01\end{array}$ \\
\hline $\begin{array}{l}\text { Viscosity at } 22 \pm 0.1^{\circ} \mathrm{C}, 3 \mathrm{rpm} \text { speed } \\
(\text { mean } \pm \mathrm{SD}, \mathrm{n}=3)\left(\mathrm{cP}^{*} \mathbf{1 0}^{2}\right)\end{array}$ & $\begin{array}{c}164.677 \pm \\
5.312\end{array}$ & $\begin{array}{c}162.24 \pm \\
5.223\end{array}$ & $\begin{array}{c}162.23 \pm \\
4.874\end{array}$ & $\begin{array}{c}161.27 \pm \\
6.112\end{array}$ & $\begin{array}{c}152.29 \pm \\
9.447\end{array}$ & $\begin{array}{c}151.20 \pm \\
3.222\end{array}$ & $\begin{array}{c}150.21 \pm \\
7.411\end{array}$ & $\begin{array}{c}137.20 \pm \\
4.011\end{array}$ \\
\hline Isohydrafural content (\%) & 99.99 & 99.98 & 99.96 & 99.95 & 99.92 & 99.89 & 99.87 & 98.76 \\
\hline Methyluracil content (\%) & 99.99 & 99.97 & 99.96 & 99.94 & 99.91 & 99.88 & 99.86 & 98.27 \\
\hline \multicolumn{9}{|c|}{ Strains, MIC/MBC $(\mu \mathrm{g} / \mathrm{mL})$} \\
\hline \multirow{2}{*}{ Staphylococcus aureus 209-P } & $0.97 /$ & $0.97 /$ & $0.97 /$ & $0.97 /$ & $0.97 /$ & $0.97 /$ & $0.97 /$ & $2.88 /$ \\
\hline & 0.97 & 0.97 & 0.97 & 0.97 & 0.97 & 0.97 & 0.97 & 2.88 \\
\hline \multirow{2}{*}{ Enterococcus faecalis } & $7.8 /$ & $7.8 /$ & $7.8 /$ & $7.8 /$ & $7.8 /$ & $7.8 /$ & $7.8 /$ & $9.1 /$ \\
\hline & 62.5 & 62.5 & 62.5 & 62.5 & 62.5 & 62.5 & 62.5 & 68.7 \\
\hline \multirow{2}{*}{ Escherichia coli } & $3.9 /$ & $3.9 /$ & $3.9 /$ & $3.9 /$ & $3.9 /$ & $3.9 /$ & $3.9 /$ & $4.2 /$ \\
\hline & 3.9 & 3.9 & 3.9 & 3.9 & 3.9 & 3.9 & 3.9 & 4.2 \\
\hline \multirow{2}{*}{ Klebsiella pneumoniae } & $31.25 /$ & $31.25 /$ & $31.25 /$ & $31.25 /$ & $31.25 /$ & $31.25 /$ & $31.25 /$ & $42.5 /$ \\
\hline & 62.5 & 62.5 & 62.5 & 62.5 & 62.5 & 62.5 & 62.5 & 72.5 \\
\hline \multirow{2}{*}{ Pseudomonas aeruginosa } & $31.25 /$ & $31.25 /$ & $31.25 /$ & $31.25 /$ & $31.25 /$ & $31.25 /$ & $31.25 /$ & $42.5 /$ \\
\hline & 31.25 & 31.25 & 31.25 & 31.25 & 31.25 & 31.25 & 31.25 & 34.5 \\
\hline \multirow{2}{*}{ Proteus vulgaris } & $7.8 /$ & $7.8 /$ & $7.8 /$ & $7.8 /$ & $7.8 /$ & $7.8 /$ & $7.8 /$ & $9.8 /$ \\
\hline & 7.8 & 7.8 & 7.8 & 7.8 & 7.8 & 7.8 & 7.8 & 9.8 \\
\hline
\end{tabular}

Abbreviations: Y, yellowish; H, homogenous

\section{Stability studies}

The stability studies were performed for the optimal formulation by long-term testing. [31]. The results are presented in table (Table V).

The results of the stability studies revealed that the optimal formulation was stable within 24 months as no changes in colour, odour, homogeneity, $\mathrm{pH}$, viscosity, antibacterial activity and drug content were observed (Table V). At 30 months the changes of colour, $\mathrm{pH}$, viscosity, antibacterial activity and drug content were noted, which indicated that the ointment did not correspond the requirements.

\section{Conclusions}

A combination of $0.1 \%$ isohydrafural and $4 \%$ methyluracil in a hydrophilic base ointment of PEG 400 and PEG 1500 was developed in order to improve the treatment of skin and soft tissue infections. DSC and FTIR-Spectroscopy results confirmed the physical and chemical compatibility of isohydrafural, methyluracil, PEG 400 and PEG 1500. The optimal formulation was $\mathrm{F} 4$ with the composition: $76.72 \%$ of PEG 400 and $19.18 \%$ of PEG 1500 , as it has optimal values of viscosity at $22 \pm 0.1^{\circ} \mathrm{C}-176.51$ $\mathrm{cP} * 10^{2}$ and at $37 \pm 0.1^{\circ} \mathrm{C}-101.41 \mathrm{cP} * 10^{2}$ at the 
FARMACIA, 2019, Vol. 67, 5

lowest shear rate and it is capable of a high osmotic activity $-301.10 \%$ in comparison with the rest of the formulations.

The in vitro antibacterial activity of the optimal formulation of $0.1 \%$ isohydrafural and $4 \%$ methyluracil indicated that it is more potent against Grampositive and Gram-negative bacteria compared to Nitrofural $2 \%$ ointment. The long-term stability testing of the optimized ointment formulation of isohydrafural and methyluracil revealed the shelf-life of two years.

\section{References}

1. $\quad * * * I C H$ Harmonised Tripartite Guideline $Q 1 A(R 2)$ : Stability Testing of New Drug Substances and Products, 2003.

2. ***ICH Harmonised Tripartite Guideline, Validation of analytical procedures: text and methodology Q2(R1). Step 5: Note for guidance on validation of analytical procedures: text and methodology (CPMP/ICH/381/95), 2006.

3. ***ICH Harmonised Tripartite GuidelineTopic $Q 1 C$ : Stability Testing For New Dosage Forms, 2003.

4. Achim M, Tomuta I, Vlase L, Iuga C, Moldovan M, Leucuta SE, Paclitaxel-loaded poly(lactic-coglycolic acid) microspheres: preparation and in vitro evaluation. J Drug Deliv Sci Tech., 2008; 18(6): 410-416.

5. Arya SC, Agarwal N, Agarwal S, Nitrofurantoin: an effective and ignored antimicrobial. Intern $J$ Antimicrob Agents, 2006; 27(4): 354-355.

6. Banerjee $\mathrm{S}$, Argaez $\mathrm{C}$, Topical antibiotics for infection prevention: A review of the clinical effectiveness and guidelines. Ottawa (ON): Canadian Agency for Drugs and Technologies in Health; 2017 March 27. www.ncbi.nlm.nih.gov.

7. Bezerra G, Pereira M, Ostrosky E, Barbosa E, de Moura M, Ferrari M, Aragao C, Compatibility study between ferulic acid and excipients used in cosmetic formulations by TG/DTG, DSC and FTIR. J Therm Anal Calorim., 2017; 127(2): 1683-1691.

8. Chadha R, Bhandari S, Drug-excipient compatibility screening - Role of thermoanalytical and spectroscopic techniques. J Pharm Biomed Anal., 2014; 87: 82-97.

9. da Silveira LM, Fiorot AB, Xavier TP, Yoshida MI, de Oliveira MA, Drug-excipient compatibility assessment of solid formulations containing meloxicam. Eur J Pharm Sci., 2018; 112: 146-151.

10. Dinte E, Bodoki E, Leucuta S, Iuga CA, Compatibility studies between drugs and excipients in the preformulation phase of buccal mucoadhesive systems. Farmacia, 2013; 61(4): 703-712.

11. Donici E, Development and validation of spectrophotometric method in ultraviolet and visible of assay of fluocinolone acetonide from combined ointment: experimental study. MJHS, 2017; 13(3): 53-58.

12. Fair RJ, Tor Y, Antibiotics and bacterial resistance in the 21st century. Perspect Medicin Chem., 2014; 6: 25-64.

13. Garg T, Rath G, Goyal AK, Comprehensive review on additives of topical dosage forms for drug delivery. Drug Deliv., 2015; 22(8): 969-987.
14. Ghannadi A, Karimzadeh H, Tavakoli N, Darafsh M, Ramezanloo P, Efficacy of a Combined Rosemary and Lavender Topical Ointment in the Treatment of Patients with Osteoarthritis of the Knee. Zahedan J Res Med Sci., 2013; 15(6): 29-33.

15. Kaur R, Sinha VR, Use of thermal and non thermal techniques for assessing compatibility between mirtazapine and solid lipids. J Pharm Biomed Anal., 2018; 161: 144-158.

16. $\mathrm{Ki} \mathrm{V}$, Rotstein $\mathrm{C}$, Bacterial skin and soft tissue infections in adults: A review of their epidemiology, pathogenesis, diagnosis, treatment and site of care. Can J Infect Dis Med Microbiol., 2008; 19(2): 173-184.

17. Kumar V, Antimicrobial potential of hydrazone scaffold. Int J Acad Res Dev., 2018; 3(2): 9-12.

18. Mastropietro DJ, Nimroozi R, Omidian H, Rheology in Pharmaceutical Formulations - a Perspective. $J$ Develop Drugs, 2013; 2(2): 108.

19. Mesnukul A, Yodkhum K, Phaechamud T, Solid Dispersion Matrix Tablet Comprising IndomethacinPEG-HPMC Fabricated with Fusion and Mold Technique. Indian J Pharmaceutic Sci., 2009; 71(4): 413-420.

20. Muherei M, Common Versus Herschel-Bulkley Drilling Fluid Models: Effect of Their Rheological Parameters on Dynamic Particle Settling Velocity. Am Sci Res J Engin Tech Sci. (ASRJETS), 2016; 16(1): 155-177.

21. Prisacari V, Buraciov S, Dizdari A, Stoleicov S, Izohidrafural - new antibacterial remedy. Communication II. The study of toxicity, dermatoresorptive irritating features as vell as the experimental therapeutic action. Scientific Annals of the "Nicolae Testemitanu" State University of Medicine and Pharmacy, 2003; 1: 243-247. (available in Romanian)

22. Prisacari V, Buraciov S, Dizdari A, Stoleicov S, Diug E, Izohidrafural - new antibacterial remedy. Communication I. The study of antibacterial activity. Scientific Annals of the "Nicolae Testemitanu" State University of Medicine and Pharmacy, 2003; 1: 240-243. (available in Romanian)

23. Prisacari V, Buraciova S, Dizdari A, Tapcov V, Gulea A, Birca M, Bodrug M, Coltun M, New antibacterial and antifungal substances from local raw material. Akademos, 2010; 2(17): 66-75. (available in Romanian)

24. Prisacari V, Ciaica T, Tapcov V, Samusi N, inventors. Isonicotinoylhydrazone of 5-nitro-2-furan aldehyde. Republic of Moldova Patent, 1994. No. 196 B1. (available in Romanian)

25. Rezvani M, Uzlenkova N, Whitehouse E, Frenkel L, Wilkinson JH, Ross G, Morris GM, Hopewell JW, Pilipenko N, Effects of Lipochromin and Levosinum in the modulation of radiation-induced injury to pig skin. Br J Radiol., 2000; 73(871): 771-775.

26. Rowe RC, Sheskey PJ, Cook WG, Fenton ME, Handbook of pharmaceutical excipients $-7^{\text {th }}$ ed. London: Pharmaceutical Press and American Pharmacists Association; 2009.

27. Rus LM, Iurian S, Kacso I, Borodi G, Porav S, Heghes SC, Iuga CA, Tomuta I, Development of meloxicam oral lyophilisates: role of thermal analysis and complementary techniques. Farmacia, 2019; 67(1): 56-67. 
28. Rus LM, Tomuta I, Iuga C, Maier C, Kacso I, Borodi G, Bratu I, Bojita M, Compatibility studies of indapamide/pharmaceutical excipients used in tablet preformulation. Farmacia, 2012; 60(1): 92101.

29. Savkare AD, Wakhare RK, Review on the fixed dose combination drugs and their incompatibilities. IJPSR, 2017; 8(7): 2798-2807.

30. Thomson KS, Thomson GK, Biehle J, Deeb A, Crawford J, A Novel Topical Combination Ointment with Antimicrobial Activity against MethicillinResistant Streptococcus aureus, Gram-Negative Superbugs, Yeasts, and Dermatophytic Fungi. Curr Ther Res Clin Exp., 2016; 83: 8-12.

31. Uncu L, Vislouh O, Bobrov E, Valica V, Prisacari V, Suvorchina O, Treapitina T, Stability study and determination of the shelf life of the ointment "Izofural". Scientific Annals of the "Nicolae Testemitanu" State University of Medicine and Pharmacy, 2012; 1(13): 254-259. (available in Romanian)

32. Zhang X, Wang X, Li C, Wang Y, Feng H, Xu T, A quantification of diffusion dialysis process: Single electrolyte system (hydrochloric acid solution). Chem Engin Sci., 2015; 135: 547-552.

33. Chadaev AP, Nurpisov AM, Experimental and clinical study of immunomodulators Immunomax and Gepon in complex treatment of acute purulent surgical infection. Antibiotics and Chemoterapy, 2004; 49(7): 9-16.

34. Nizhenkovska I, Gorchakova N, Zaychenko G, Narokha V, Uracil as the basis for medication creation. Current Topics in Pharmacology, 2018; 22: 19-26.

35. Inoue $\mathrm{Y}$, Maeda R, Furuya $\mathrm{K}$, Isamu M, Masayuki $\mathrm{K}$, Kanamoto I, Relationship between the usability and physicochemical properties of triamcinolone acetonide ointments. Results in Pharma Sciences, 2013; 3: 15-19.

36. Georgescu M, Tăpăloagă PR, Tăpăloagă D, Furnaris F, Ginghină O, Negrei C, Giuglea C, Bălălău C, Ștefãnescu E, Popescu IA, Georgescu D, Evaluation of antimicrobial potential of Nigella sativa oil in a model food matrix. Farmacia, 2018; 66(6): 10281036.

37. Toiu A, Vlase L, Gheldiu AM, Vodnar D, Oniga I, Evaluation of the antioxidant and antibacterial potential of bioactive compounds from Ajuga reptans extracts. Farmacia, 2017; 65(3): 351-355.

38. Dua K, Malipeddi VR, Madan J, Gupta G, Awasthi R, Kikuchi IS, Pinto TA, Norfloxacin and metronidazole topical formulations for effective treatment of bacterial infections and burn wounds. Interv Med Appl Sci., 2016; 8(2): 68-76.

39. Song KW, Kim YJ, Lee CH, Rheological behaviour of semi-solid ointment base (vaseline) in steady shear flow fields. J Kor Pharm Sci.,2007; 37(3): 137-148.

40. Maksudova F, Karieva E, Investigations of rheological properties of diclofenac sodium gel preparation. MHSJ, 2013; 14(2): 91-94. 